\title{
Purification and Some Properties of a Low Endo-type Cellulase from Acremonium cellulolyticus
}

(Received June 21, 2002; Accepted August 12, 2002)

\author{
Takanori Nihira, ${ }^{1}$ Supannee Kansarn, ${ }^{1}$ Toshiaki Kono ${ }^{2}$ and Gentaro Okada ${ }^{1,3, *}$ \\ 'The Graduate School of Electronic Science and Technology, Shizuoka University \\ (3-5-1, Johoku, Hamamatsu, Shizuoka 432-8561, Japan) \\ ${ }^{2}$ Health and Bioscience Laboratories, Meiji Seika Kaisha, Ltd. (5-3-1, Chiyoda, Sakado, Saitama 350-0289, Japan) \\ ${ }^{3}$ Department of Biology, Faculty of Education, Shizuoka University (836, Ohya, Shizuoka 422-8529, Japan)
}

\begin{abstract}
A distinct endo-cellulase component derived from Acremonium cellulase, a commercial cellulase material from Acremonium cellulolyticus, was extensively purified by consecutive column chromatography and was designated as cellulase I. Cellulase I was homogeneous on both Native- and SDS-PAGE, and was completely free from $\beta$-glucosidase. The enzyme showed high specific activity for Avicel and extremely low specific activity for $\mathrm{CMC}, 0.69$ and $0.40 \mathrm{U} / \mathrm{mg}$ of protein, respectively. The molecular mass (SDS-PAGE) and pI value of cellulase I were about $61 \mathrm{kDa}$ and 5.0, respectively. The purified enzyme contained $19.8 \%$ carbohydrate as glucose. The $\mathrm{N}$-terminal amino acid sequence from the 2 nd up to the 20 th residue of the enzyme was Q- *-V-W-G-Q- *-G-G-Q-G-W-S-G-A-T-(S)- *-A-. The optimum pH and temperature for cellulase I were 5.0 and $55^{\circ} \mathrm{C}$, respectively. Cellulase $\mathrm{I}$ was completely stable over the range of pH 3.0-6.0 at $4^{\circ} \mathrm{C}$ for $24 \mathrm{~h}$ and at temperatures below $55^{\circ} \mathrm{C}$. The activity of cellulase I was partially inactivated by $5 \mathrm{mM} \mathrm{Mn}^{2+}, \mathrm{Fe}^{3+}, \mathrm{Hg}^{2+}$ and $\mathrm{KMnO}_{4}$ to various inhibition extents. Cellulase I split various cellulosic substrates to produce predominant cellobiose and a small amount of glucose as the final hydrolysis products. The enzyme was characterized as an exceedingly low endo-type cellulase on the basis of its actions on both CMC and cellooligosaccharides.

Key words: Acremonium cellulolyticus, low endo-type cellulase, purification, column chromatography, cellooligosaccharides
\end{abstract}

The biological degradation of native cellulose is an extremely important process for the carbon cycle in nature, both ecologically and commercially. It is generally accepted that most cellulolytic microorganisms produce several cellulase $[1,4-(1,3 ; 1,4)-\beta$-D-glucan 4 -glucanohydrolase, EC 3.2.1.4] components, which together constitute a "cellulase system" that solubilizes highly ordered native cellulose by their synergistic actions.

Okada et al. have reported several papers on the cellulase system of Trichoderma viride. ${ }^{1-7)} \mathrm{We}$ are presently focusing our research efforts on the complete elucidation of the cellulase system of a filamentous fungus, Acremonium cellulolyticus, which possesses exceedingly potent activity toward native cellulose.

In previous papers, ${ }^{8,9)}$ we reported that Acremonium cellulase, a commercial cellulase preparation from $A$. cellulolyticus, could be resolved into three cellulase peak fractions (Peaks I, III and IV) upon chromatography on a QAE-Toyopearl 550C column. The highly purified cellulases III-A, III-B and IV, were obtained from the Peaks III and IV cellulase fractions, respectively, and were char-

\footnotetext{
${ }^{*}$ Corresponding author (Tel. +81-45-924-5783, Fax. +81-45924-5836, E-mail: jinpei@ceres.dti.ne.jp).

Abbreviations: QAE, quaternary amino ethyl; DEAE, diethyl amino ethyl; PAGE, polyacrylamide gel electrophoresis; SDS, sodium dodecyl sulfate; CMC, sodium carboxymethyl cellulose; PNPG, $p$-nitrophenyl $\beta$-D-glucoside; $\mathrm{G}_{1}$, D-glucose; $\mathrm{G}_{2}-\mathrm{G}_{6}$, cellooligosaccharides from cellobiose to cellohexaose; NBS, $N$ bromosuccinimide; EDTA, ethylendiaminetetraacetic acid; FPLC, fast-protein liquid chromatography; HPLC, high-performance liquid chromatography.
}

acterized physicochemically and enzymologically.

In this paper, we describe the purification and characterization of a distinct cellulase component with a high level of Avicel-saccharification activity from the Peak I fraction, and also the comparisons of some of its properties with those of the other three purified cellulases studied previously. ${ }^{8,9)}$

\section{MATERIALS AND METHODS}

Crude enzyme material. A spray-dried cellulase powder from the culture filtrate of Acremonium cellulolyticus (Acremonium cellulase, Lot No. AUS-0301) was kindly supplied by Meiji Seika Kaisha, Ltd., Japan, and was used in this study.

Materials. CMC, Avicel, filter paper, absorbent cotton and PNPG were the same products as described previously, ${ }^{8,9)}$ and were used as substrates. QAE-Toyopearl 550C and DEAE-Toyopearl 650S were the products of Tosoh, Japan, Bio-Gel P-100 was from Bio-Rad Laboratories, USA, and Alkyl-Superose was from Amersham Pharmacia Biotech, Sweden. All other reagents were of analytical grade.

Enzyme assays. CMC-, Avicel- and other cellulosic substrate-saccharification activities, and aryl $\beta$-glucosidase activity were measured as described previously. ${ }^{899}$ Each enzyme unit $(U)$ was defined in the same way as reported previously. ${ }^{8,9)}$

Protein assays. Protein content was measured by the method of Lowry et al.$^{10)}$ with crystalline bovine serum albumin as the standard. Absorbance at $280 \mathrm{~nm}$ was used 
for monitoring the protein in column effluents.

Measurement of carbohydrate. The total carbohydrate in the purified enzyme was determined by the phenol-sulfuric acid method ${ }^{11)}$ with D-glucose as the standard.

Electrophoresis. Polyacrylamide gel electrophoresis (Native-PAGE), SDS-PAGE and isoelectoric focusing were done as described previously. ${ }^{8,9)}$ In all cases, the gels were stained with a silver staining kit (Silver Stain II kit, Wako $^{12,13)}$ or $0.2 \%$ Coomassie Brilliant Blue R-250.

Analysis of $N$-terminal amino acid sequence. The Nterminal amino acid sequence of the purified enzyme was determined by repetitive Edman degradation ${ }^{14)}$ employing a protein sequencer, PE Model 492 (Perkin-Elmer Co., USA).

Viscometry. The changes in viscosity during the enzymatic hydrolysis of CMC were measured at intervals with a Cannon-Fenske viscometer $(c=0.0369)$. The enzyme activity was expressed in terms of specific fluidity $\left(\phi_{\mathrm{sp}}\right)$.

High-performance liquid chromatography (HPLC).

Cellooligosaccharides $\left(\mathrm{G}_{2}-\mathrm{G}_{6}\right)$ were prepared and identified by HPLC on a Shimadzu LC-10 system (Shimadzu Corporation) as described previously. ${ }^{8,9)}$

\section{RESULTS}

\section{Purification of the enzyme.}

Unless otherwise stated, all purification procedures for the enzymes were carried out in a cold room $\left(4^{\circ} \mathrm{C}\right)$. The operations of FPLC were done at room temperature $\left(25^{\circ} \mathrm{C}\right)$. The enzyme solution collected in each purification step was concentrated and dialyzed using a Diaflo ultrafiltration apparatus with a PM-10 membrane (Amicon Corp, USA).

A commercial cellulase powder $(5 \mathrm{~g})$ was fractionated into three cellulase fractions, named Peaks I, III and IV, by QAE-Toyopearl 550C column chromatography according to procedures reported in our preceding paper. ${ }^{8)}$ Of these three cellulase fractions, Peak I was subjected to chromatography on a DEAE-Toyopearl 650S column for further purification.

(1) DEAE-Toyopearl 650S column chromatography.

The dialyzed sample was put on a DEAE-Toyopearl $650 \mathrm{~S}$ column $(2 \times 35 \mathrm{~cm})$ pre-equilibrated with $20 \mathrm{~mm}$ acetate buffer ( $\mathrm{pH}$ 6.0). Elution was done stepwise with $20 \mathrm{mM}$ acetate buffer (pH 5.5) containing 0 and $200 \mathrm{mM}$ $\mathrm{NaCl}$ at a flow rate of $0.3 \mathrm{~mL} / \mathrm{min}$. The elution profiles are shown in Fig. 1. Peak I was fractionated into four protein fractions (F-1 to F-4). Among them, F-1 showed a high level of $\mathrm{CMC}$-saccharification activity, while $\mathrm{F}-2$ was rich in Avicel- but poor in CMC-saccharification activity. The F-2 fraction (fraction Nos. 13-20) were pooled, concentrated and dialyzed overnight against 50 $\mathrm{mM}$ acetate buffer ( $\mathrm{pH} 5.5$ ).

(2) Gel filtration on Bio-Gel P-100. The dialyzed F2 fraction was applied to a Bio-Gel P-100 column $(2 \times 80$ $\mathrm{cm})$ pre-equilibrated with $50 \mathrm{mM}$ acetate buffer $(\mathrm{pH} 5.5)$, and the column was then eluted with the same buffer at a flow rate of $0.04 \mathrm{~mL} / \mathrm{min}$. Eluate was collected in $3 \mathrm{~mL}$ volumes. Two protein peaks were separated by this chromatography. The active fractions were pooled, concen-

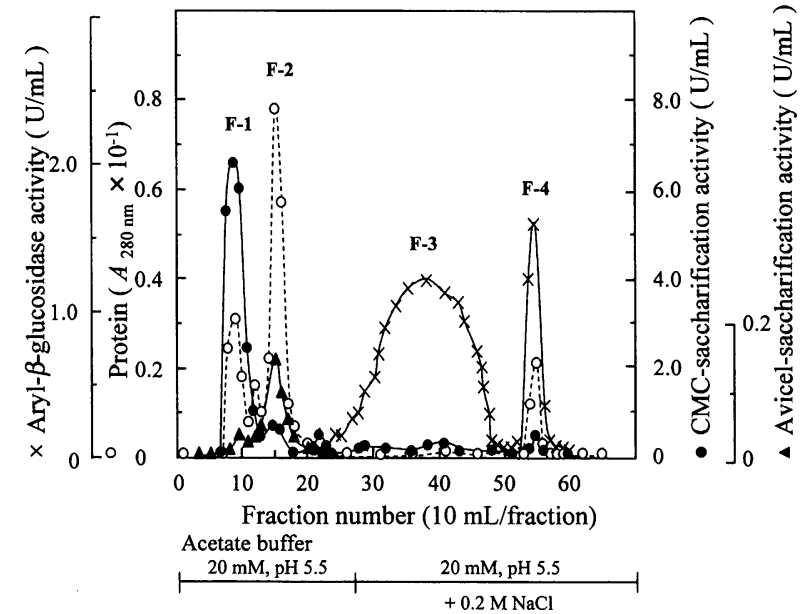

Fig. 1. Elution profiles of the Peak I fraction on DEAE-Toyopearl $650 \mathrm{~S}$ column chromatography.

O, Protein $\left(A_{280} \mathrm{~nm} \times 10^{-1}\right) ; \bullet, C M C$-saccharification activity (U/ $\mathrm{mL}) ; \boldsymbol{\Delta}$, Avicel-saccharification activity $(\mathrm{U} / \mathrm{mL}) ; \times$, Aryl- $\beta$ glucosidase activity $(\mathrm{U} / \mathrm{mL})$.

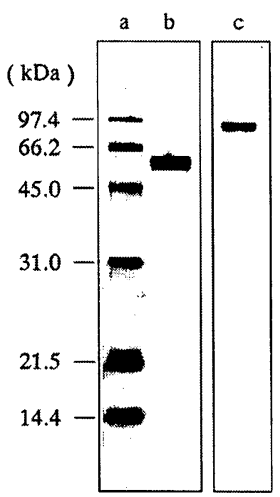

Fig. 2. Native- and SDS-PAGE of the purified cellulase.

Lane a, standard protein mixture containing phosphorylase $b$ (97.4 $\mathrm{kDa})$, bovine serum albumin (66.2), ovalbumin (45.0), carbonic anhydrase (31.0), soybean trypsin inhibitor (21.5) and lysozyme (14.4) ; lane b, cellulase I on SDS-PAGE ; lane c, cellulase I on Native-PAGE.

trated and dialyzed against $50 \mathrm{mM}$ acetate buffer (pH 5.5) containing $2 \mathrm{M}\left(\mathrm{NH}_{4}\right)_{2} \mathrm{SO}_{4}$.

(3) Alkyl-Superose column chromatography. The dialyzed sample was applied to a hydrophobic interaction chromatography using an Alkyl-Superose FPLC column $(0.5 \times 5 \mathrm{~cm})$ pre-equilibrated with $50 \mathrm{mM}$ acetate buffer (pH 5.5) containing $2 \mathrm{M}\left(\mathrm{NH}_{4}\right)_{2} \mathrm{SO}_{4}$. The column was then eluted by a linear gradient of 2 to $0 \mathrm{M}\left(\mathrm{NH}_{4}\right)_{2} \mathrm{SO}_{4}$ in the same buffer at a flow rate of $0.5 \mathrm{~mL} / \mathrm{min}$. Fractions were collected in $1 \mathrm{~mL}$ volumes and assayed for cellulase activity. A symmetrical protein peak containing both Aviceland CMC-saccharification activities was obtained. The active fractions were combined as the purified enzyme. The purified enzyme was designated as cellulase I, and it gave a single protein band on both Native- and SDS-PAGE (Fig. 2).

Table 1 summarizes the yield and specific activity of cellulase I during the purification procedure. Cellulase I had a high level of specific Avicel-saccharification activity, $0.69 \mathrm{U} / \mathrm{mg}$ of protein, but an extremely low level of specific CMC-saccharification activity, $0.40 \mathrm{U} / \mathrm{mg}$ of protein, and was used in the subsequent characterization. 
Table 1. Summary of the purification of cellulase I from A. cellulolyticus.

\begin{tabular}{|c|c|c|c|c|c|}
\hline \multirow[b]{2}{*}{ Purification step } & \multirow[b]{2}{*}{$\begin{array}{l}\text { Total }^{*} \\
\text { protein } \\
(\mathrm{mg})\end{array}$} & \multicolumn{3}{|c|}{ Enzyme activity** } & \multirow[b]{2}{*}{$\begin{array}{l}\text { Purification } \\
\text { (fold) }\end{array}$} \\
\hline & & $\begin{array}{l}\text { Total } \\
\text { unit }\end{array}$ & $\begin{array}{l}\text { Yield } \\
(\%)\end{array}$ & $\begin{array}{l}\text { Specific } \\
\text { activity } \\
(\mathrm{U} / \mathrm{mg})\end{array}$ & \\
\hline $\begin{array}{l}\text { 1. Crude cellulase } \\
\text { extract }\end{array}$ & 3750.0 & 787.5 & 100.0 & 0.21 & 1.0 \\
\hline $\begin{array}{l}\text { 2. QAE-Toyopearl } \\
550 \mathrm{C}\end{array}$ & 1983.8 & 476.1 & 60.5 & 0.24 & 1.1 \\
\hline $\begin{array}{l}\text { 3. DEAE-Toyopearl } \\
650 \mathrm{~S}\end{array}$ & 578.4 & 173.5 & 22.0 & 0.30 & 1.4 \\
\hline 4. Bio-Gel P-100 & 320.6 & 134.7 & 17.1 & 0.42 & 2.0 \\
\hline $\begin{array}{l}\text { 5. Alkyl-Superose } \\
\text { (cellulase I) }\end{array}$ & 178.4 & 123.1 & 15.6 & 0.69 & 3.3 \\
\hline
\end{tabular}

${ }^{*}$ Measured by the method of Lowry et al.${ }^{10) * *}$ Avicel was used as a substrate.

Physicochemical properties of the purified enzyme.

The molecular mass of cellulase I was estimated to be about $61 \mathrm{kDa}$ by the comparison of relative mobilities on SDS-PAGE with those of standard proteins (Fig. 2). The isoelectric point of cellulase I was determined to be about 5.0 by isoelectric focusing. Cellulase I contained $19.8 \%$ carbohydrate (as glucose).

Concerning the $\mathrm{N}$-terminal amino acid sequence of the purified enzyme, the first amino acid was not detected by Edman degradation, indicating the presence of a modified amino acid residue at the $\mathrm{N}$-terminus. Therefore, the $\mathrm{N}$ terminal amino acid sequence was analyzed by Edman degradation after the purified enzyme was subjected to the pyroglutamate aminopeptidase treatment by the method of Podell and Abraham ${ }^{15)}$ The N-terminal amino acid sequence from the 2 nd up to the 20th residue of cellulase I is shown in Fig. 3.

\section{Effects of $p H$ and temperature on the activity of the purified enzyme.}

The effects of $\mathrm{pH}$ and temperature on the activities of the purified cellulase were studied under the standard assay conditions toward $2 \%$ Avicel at $40^{\circ} \mathrm{C}$ for 20 min using $50 \mathrm{mM}$ McIlvaine buffers ( $\mathrm{pH} 2.5^{-8.0}$ ) and at different reaction temperatures for $10 \mathrm{~min}$. The optimum $\mathrm{pH}$ and temperature for cellulase I was 5.0 and $55^{\circ} \mathrm{C}$, respectively.

\section{Stability of the purified enzyme toward $\mathrm{pH}$ and tem-} perature.

Two series of enzyme solutions were prepared, each solution containing an equal amount of the purified enzyme $(0.15 \mathrm{U}$ each) individually adjusted to a $\mathrm{pH}$ value from 2.5 to 12.0 by adding $50 \mathrm{~mm}$ Mcllvaine or BrittonRobinson buffer. After one set of solutions of each en-

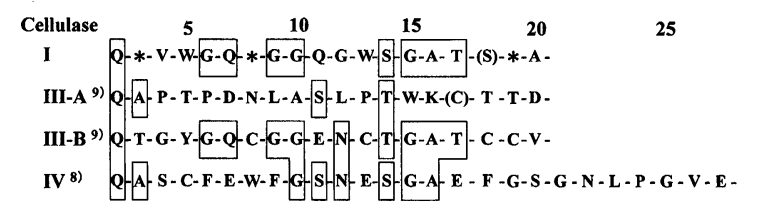

Fig. 3. N-terminal amino acid sequences of the purified cellulase.

For comparison, the data obtained for cellulases III-A, ${ }^{9)}$ III-B ${ }^{9)}$ and $\mathrm{IV}^{8)}$ are also shown. zyme had been kept at $4^{\circ} \mathrm{C}$ for $24 \mathrm{~h}$ and the other set at $45^{\circ} \mathrm{C}$ for $2 \mathrm{~h}$, both series of buffered enzyme solution were diluted with a suitable volume of $50 \mathrm{mM}$ Mcllvaine (pH 5.0). Each $250 \mu \mathrm{L}$ enzyme sample was then examined for remaining Avicel-saccharification activity by the standard assay at $40^{\circ} \mathrm{C}$ for $20 \mathrm{~min}$. Cellulase I was stable over the ranges of $\mathrm{pH} 3.0-6.0$ at $4^{\circ} \mathrm{C}$ for $24 \mathrm{~h}$ and of $\mathrm{pH}$ $4.0-6.0$ at $45^{\circ} \mathrm{C}$ for $2 \mathrm{~h}$.

The purified enzyme $(0.03 \mathrm{U}, \mathrm{pH} 5.0)$ was heated at various temperatures for $10 \mathrm{~min}$ and then cooled immediately in an ice-bath. The remaining Avicel-saccharification activity was then measured by the standard assay at $30^{\circ} \mathrm{C}$ for $10 \mathrm{~min}$. Cellulase I was completely stable at temperatures below $55^{\circ} \mathrm{C}$.

\section{Effects of various metal ions and several enzyme in- hibitors on enzyme activity.}

The purified enzyme was incubated with an equal volume of each metal ion or enzyme inhibitor solution (10 $\mathrm{mM}, \mathrm{pH} 6.0$ ) at $30^{\circ} \mathrm{C}$ for $30 \mathrm{~min}$. Then the mixtures were diluted 10 -fold with $50 \mathrm{~mm}$ acetate buffer $(\mathrm{pH} \mathrm{5.0)}$ ) and the remaining enzyme activity of each reaction mixture containing $0.03 \mathrm{U}$ of enzyme was examined by the standard assay at $30^{\circ} \mathrm{C}$ for $10 \mathrm{~min}$. Inactivations of cellulase I were found to be partial with $5 \mathrm{mM} \mathrm{Mn}{ }^{2+}, \mathrm{Fe}^{3+}, \mathrm{Hg}^{2+}$ and $\mathrm{KMnO}_{4}$.

Mode of action of the purified enzyme toward CMC.

The mode of action of the purified enzyme toward CMC was analyzed by viscometry as described previously. ${ }^{8,9)}$ The reaction mixture was composed of $6 \mathrm{~mL}$ of $50 \mathrm{mM}$ acetate buffer (pH 5.0) containing $0.5 \% \mathrm{CMC}$ and $6 \mathrm{~mL}$ of the enzyme solution $(0.25 \mathrm{U})$. The results are shown in Fig. 4. For comparison, the data obtained for cellulases III-A,9) III-B) and IV ${ }^{8)}$ are also shown in this figure.

\section{Action of the purified enzyme on cellooligosaccha- rides.}

The reaction mixture was comprised of $4 \mathrm{mM}$ of each

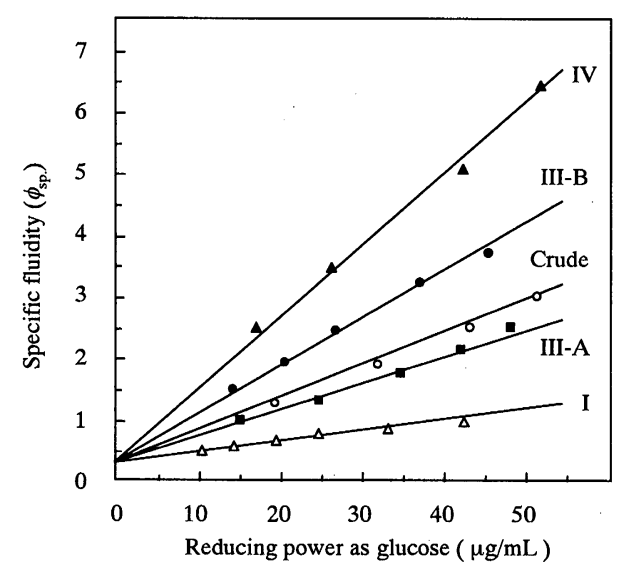

Fig. 4. Relationship between increases in specific fluidity and reducing power during the hydrolysis of CMC using the purified cellulase.

For comparison, the data obtained for cellulases III-A, ${ }^{9)}$ III-B ${ }^{9)}$ and $\mathrm{IV}{ }^{8}{ }^{8}$ and a crude enzyme preparation are also shown. $\triangle$, cellulase I ; $\boldsymbol{\square}$, cellulase III-A ; $\bullet$, cellulase III-B ; $\boldsymbol{\Delta}$, cellulase IV ; $\bigcirc$, crude enzyme preparation. 
Table 2. Degree of hydrolysis and product distribution for cellooligosaccharides due to the action of cellulase I at the initial and late stages of incubation.

\begin{tabular}{|c|c|c|c|c|c|c|c|c|}
\hline \multirow{2}{*}{$\begin{array}{l}\text { Substrate } \\
(4 \mathrm{mM})\end{array}$} & \multirow{2}{*}{$\begin{array}{c}\text { Degree of hydrolysis* } \\
(\%)\end{array}$} & \multirow{2}{*}{$\begin{array}{l}\text { Time } \\
(\min )\end{array}$} & \multicolumn{6}{|c|}{ Product distribution (mM) } \\
\hline & & & $\mathrm{G}_{6}$ & $\mathrm{G}_{5}$ & $\mathrm{G}_{4}$ & $\mathrm{G}_{3}$ & $\mathrm{G}_{2}$ & $\mathrm{G}_{1}$ \\
\hline \multirow{2}{*}{ Cellohexaose } & 97.3 & 2 & 1.59 & $<0.01$ & 0.11 & 4.24 & 4.78 & 0.03 \\
\hline & 98.3 & 240 & 0.07 & $<0.01$ & $<0.01$ & 2.94 & 6.24 & 1.42 \\
\hline \multirow{2}{*}{ Cellopentaose } & 98.8 & 2 & - & 0.05 & 0.04 & 4.08 & 3.46 & 0.06 \\
\hline & 100.0 & 240 & - & - & $<0.01$ & 2.78 & 4.92 & 1.26 \\
\hline \multirow{2}{*}{ Cellotetraose } & 45.8 & 2 & - & - & 2.17 & 0.19 & 3.90 & $<0.01$ \\
\hline & 99.0 & 240 & - & - & 0.04 & 0.16 & 7.44 & 0.48 \\
\hline \multirow{2}{*}{ Cellotriose } & 7.5 & 10 & - & - & - & 3.70 & 0.29 & 0.29 \\
\hline & 60.5 & 240 & - & - & - & 1.58 & 2.40 & 2.22 \\
\hline
\end{tabular}

${ }^{*}$ Calculated from the amount of residual substrate.

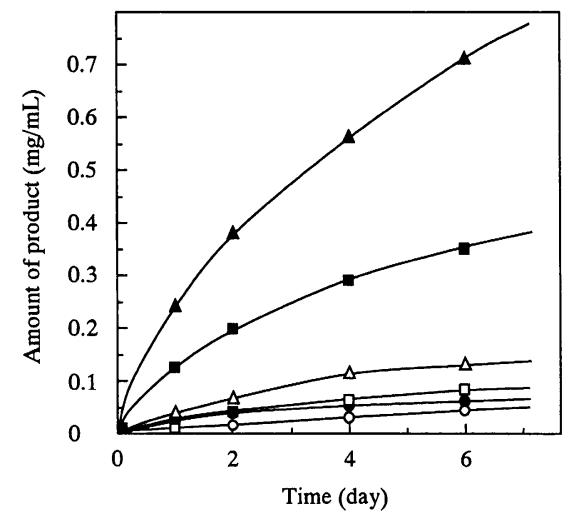

Fig. 5. Courses of reducing sugar and glucose formation due to the action of cellulase I on insoluble substrates.

-, reducing sugar from absorbent cotton; $\bigcirc$, glucose from absorbent cotton ; $\mathbf{\square}$, reducing sugar from filter paper ; $\square$, glucose from filter paper ; $\Delta$, reducing sugar from Avicel ; $\Delta$, glucose from Avicel.

cellooligosaccharide $\left(\mathrm{G}_{2}-\mathrm{G}_{6}\right)$ and cellulase solution $(0.005$ $\mathrm{U}$ ) in $0.4 \mathrm{~mL}$ of $10 \mathrm{mM}$ acetate buffer ( $\mathrm{pH} \mathrm{5.0)}$. The reaction mixture was incubated at $30^{\circ} \mathrm{C}$ for an appropriate period. The hydrolysis products derived from cellooligosaccharides using cellulase I were analyzed by HPLC. Table 2 shows the degree of hydrolysis and product distribution due to the action of cellulase $I$ at the initial and late stages of incubation. Cellulase I hydrolyzed $\mathrm{G}_{6}, \mathrm{G}_{5}$ and $G_{4}$ to give $G_{2}$ as a major end product. The enzyme preferred to attack the middle $\beta$-1,4-glucosidic linkage in the $\mathrm{G}_{4}$ molecule to give $\mathrm{G}_{2}$ as a major product. Cellulase I did not act entirely on $\mathrm{G}_{2}$.

Action of the purified enzyme on insoluble substrates.

Avicel, filter paper and absorbent cotton were used as insoluble substrates. The reaction mixture contained 40 $\mathrm{mg}$ of each substrate and $2 \mathrm{~mL}$ of the purified enzyme $(60 \mu \mathrm{g})$ in $50 \mathrm{~mm}$ acetate buffer ( $\mathrm{pH} \mathrm{5.0)}$. Other assay conditions were identical as described previously. ${ }^{8,9)}$

As shown in Fig. 5, it is clear that cellulase I is capable of producing a high level of reducing sugar (mostly cellobiose) and a small amount of glucose from both Avicel and filter paper. On the other hand, it was difficult to hydrolyse absorbent cotton using this enzyme in a short-term incubation.

\section{DISCUSSION}

A purified cellulase component was separated from
Acremonium cellulase, a crude cellulase preparation of $A$. cellulolyticus, by consecutive column chromatographies of QAE-Toyopearl 550C, DEAE-Toyopearl 650S, Bio-Gel P-100 and Alkyl-Superose, and was designated as cellulase I. Cellulase I was homogeneous on both Native- and SDS-PAGE, and was completely free from $\beta$-glucosidase.

Of the purified cellulases I, III-A, ${ }^{9)}$ III- ${ }^{9)}$ and IV, ${ }^{8)}$ cellulases I and IV showed the lowest and highest value of specific activity for CMC, respectively. On the contrary, cellulases I and IV showed the highest and lowest value of specific activity for Avicel, respectively.

The molecular mass of cellulase I $(61 \mathrm{kDa})$ showed the largest value compared to those of cellulases III-A (58 $\mathrm{kDa})$, III-B (49 $\mathrm{kDa})$ and IV $(38 \mathrm{kDa})$ reported in previous papers. ${ }^{8,9)}$ As is the case of other purified cellulases, cellulase $I$ was an acidic protein judging from its $\mathrm{p} I$ value (5.0). Cellulase I contained a considerable amount of carbohydrates (19.8\% as glucose). This suggests that the purified enzyme seems to be a glycoprotein, as most extracellular enzymes from fungi are. As described in Results, the N-terminus amino acids of cellulases I, III-A, III-B and IV were all modified. Pyroglutamic acid was suggested as the N-terminal amino acid in all purified cellulases judging from the results by pyroglutamate aminopeptidase treatment. As shown in Fig. 3, only one identical amino acid at the position of the 2 nd residue from each $\mathrm{N}$-terminus is conserved among these four cellulases. Furthermore, cellulase I showed homologies of 40 and $25 \%$ with cellulases III-B and IV, respectively, from the $\mathrm{N}$-terminus up to the 20th residue. According to the data of amino acid sequences by BLAST, ${ }^{16-18)}$ cellulases I and III-B showed a high level of homology with Penicillium janthinellum endo-glucanase II $(80 \%)^{19)}$ and Phanerochaete chrysosporium cellulose binding protein $(88 \%)^{20)}$ from the N-terminus up to the 20th residue.

The activity expressions of the four purified cellulases (I, III-A, III-B and IV) showed similar behavior toward various metal ions and several enzyme inhibitors. Inactivations of these cellulases were found to be partial with 5 $\mathrm{mM} \mathrm{Mn}{ }^{2+}, \mathrm{Fe}^{3+}, \mathrm{Hg}^{2+}$ and $\mathrm{KMnO}_{4}$ to various inhibition extents. On the other hand, EDTA, NBS and other metal ions tested had no inhibitory effect on the activities of these cellulases. This suggests that metals and sulfhydryl groups are not essential for the cellulolytic actions of the enzyme, as is the case of highly purified cellulases from Trichoderma viride. ${ }^{2,4)}$

The degree of endo-lytic action in the hydrolysis of 
CMC by the four purified cellulases from A. cellulolyticus is shown in Fig. 4. There are significant differences in the slopes ( $\phi_{\mathrm{sp} .} /$ R.P.) of the lines obtained for the four cellulases. This indicates that the mode of degradation by cellulase I is the lowest endo-lytic, and cellulase IV is by far the most endo-lytic among these four cellulases.

To investigate substrate specificity of the enzyme, saccharification capacities of the purified cellulases were examined using various cellulosic substrates. The enzyme was incapable of attacking either $\mathrm{G}_{2}$ or PNPG; however, it hydrolyzed many other substrates, such as cellooligosaccharides $\left(\mathrm{G}_{3}-\mathrm{G}_{6}\right)$, CMC, Avicel, filter paper and absorbent cotton, to various extents.

At first, cellulase I was thought to be a so-called $\mathrm{CBH}$, because it showed the lowest endo-lytic fashion toward CMC compared to the other purified cellulases (Fig. 4). However, cellulase I released a large amount of cellobiose and a small amount of glucose from the insoluble cellulosic substrates tested. When a low concentration of the enzyme was briefly incubated with various kinds of cellulosic substrates, the existence of a small amount of glucose was also confirmed in every case, and cellotriose was definitely primarily released from cellohexaose. Therefore, cellulase I was characterized as an exceedingly low endo-type cellulase just like cellulase III from $T$. viride, ${ }^{6}$ this being based on its actions on both CMC and cellooligosaccharides.

The authors wish to express their gratitude to Ms. Naomi Sumida of the Pharmaceutical Technology Laboratories of Meiji Seika Kaisha, Ltd. for her help in conducting amino acid sequence analyses.

\section{REFERENCES}

1) G. Okada, K. Nisizawa and H. Suzuki: Cellulase components from Trichoderma viride. J. Biochem., 63, 591-607 (1968).

2 ) G. Okada: Enzymatic studies on a cellulase system of Trichoderma viride II. Purification and properties of two cellulases. J. Biochem., 77, 33-42 (1975).

3 ) G. Okada and K. Nisizawa: Enzymatic studies on a cellulase system of Trichoderma viride III. Transglycosylation properties of two cellulase components of random type. J. Biochem., 78, 297-306 (1975)

4 ) G. Okada: Enzymatic studies on a cellulase system of Trichoderma viride IV. Purification and properties of a less-random type cellulase. J. Biochem., 80, 913-922 (1976).

5 ) G. Okada and Y. Tanaka: A novel type of cellulase from Trichoderma viride. Agric. Biol. Chem., 52, 617-619 (1988).

6 ) G. Okada and Y. Tanaka: Nonexistence of exo-cellobiohydrolase $(\mathrm{CBH})$ in the cellulase system of Trichoderma viride. Agric. Biol. Chem., 52, 2981-2984 (1988).

7 ) G. Okada: A novel concept for the enzymatic degradation mechanism of native cellulose. in Genetics, Biochemistry and Ecology of Cellulose Degradation, K. Ohmiya, K. Hayashi, K. Sakka, Y. Kobayashi, S. Karita and T. Kimura, eds., Uni Publishers Co., Ltd., Tokyo, pp. 76-85 (1999).

8 ) S. Kansarn, N. Matsushita, T. Kono and G. Okada: Purification and characterization of an endo-cellulase from Acremonium cellulolyticus. J. Appl. Glycosci., 47, 177-186 (2000).

9 ) S. Kansarn, T. Nihira, E. Hashimoto, M. Suzuki, T. Kono and G. Okada: Purification and properties of two endo-cellulases from Acremonium cellulolyticus. J. Appl. Glycosci., 47, 293$302(2000)$.

10) O.H. Lowry, N.J. Rosebrough, A.L. Farr and R.J. Randall: Protein measurement with the folin phenol reagent. J. Biol. Chem., 193, 265-275 (1951).
11) M. Dubois, K.A. Gilles, J.K. Hamilton, P.A. Rebers and F. Smith: Colorimetric method for determination of sugars and related substances. Anal. Chem., 28, 350-356 (1956).

12) B.R. Oakley, D.R. Kirsch and N.R. Morris: A simplified ultrasensitive silver stain for detecting proteins in polyacrylamide gels. Anal. Biochem., 105, 361-363 (1980).

13) J.H. Morrisey: Silver stain for proteins in polyacrylamide gels: A modified procedure with enhanced uniform sensitivity. Anal. Biochem., 117, 307-310 (1981).

14) P. Edman: Method for determination of the amino acid sequence in peptides. Acta Chem. Scand., 4, 283-293 (1950).

15) D.N. Podell and G.N. Abraham: A technique for the removal of pyroglutamic acid from the amino terminus of proteins using calf liver pyroglutamate amino peptidase. Biochem. Biophys. Res. Commun., 81, 176-185 (1978).

16) S.F. Altschul, W. Gish, W. Miller, E.W. Myers and D.J. Lipman: Basic local alignment search tool. J. Mol. Biol., 215, 403-410 (1990).

17) S. Karlin and S.F. Altschul: Methods for assessing the statistical significance of molecular sequence features by using general scoring schemes. Proc. Natl. Acad. Sci. USA, 87, 22642268 (1990).

18) S.F. Altschul, T.L. Madden, A.A. Schäffer, J. Zhang, Z. Zhang, W. Miller and D.J. Lipman: Gapped BLAST and PSIBLAST: A new generation of protein database search programs. Nucleic Acids Res., 25, 3389-3402 (1997).

19) G. Mernitz, A. Koch, B. Henrissat and G. Schulz: Endoglucanase II (EGII) of Penicillium janthinellum: cDNA sequence, heterologous expression and promotor analysis. Curr. Genet., 29, 490-495 (1996).

20) P.R.J. Birch: Targeted differential display of abundantly expressed sequences from the basidiomycete Phanerochaete chrysosporium which contain regions coding for fungal cellulose-binding domains. Curr. Genet., 33, 70-76 (1998).

\section{糸状菌 Acremonium cellulolyticus 起源の}

低エンド型セルラーゼの精製と基本性質

仁平高則', キャンサーン スパンニー1, 河野敏明 ${ }^{2}$, 岡田嚴太郎 ${ }^{1,3}$

1 静岡大学大学院電子科学研究科

（432-8561 静岡県浜松市城北 3-5-1）

2 明治製菓株式会社ヘルス・バイオ研究所

（350-0289 埼玉県坂戸市千代田 5-3-1）

3 静岡大学教育学部 (422-8529 静岡市大谷 836)

系状菌 Acremonium cellulolyticus 起源の市販酵素製剤か ら, 各種カラムクロマトグラフィーを組み合わせ, 電気

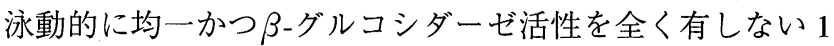
種のエンドセルラーゼ成分を高純度に精製し，セルラー ゼIと呼称した，精製酵素は，Avicelに対し高い比活性 值 $(0.69 \mathrm{U} / \mathrm{mg})$ を，また CMCに対し極めて低い比活性 值 $(0.40 \mathrm{U} / \mathrm{mg}$ )を示した. 当該酵素の分子質量 (SDS-PAGE 法）および等電点は，それぞれ約 $61 \mathrm{kDa}$ および 5.0 と推 定され，糖含量は $19.8 \%$ （グルコース換算）であった. N 末端側第 2-第 20 アミノ酸残基の配列を，エドマン分解法 にて決定した。 また, 当該酵素の酵素学的性質が精査さ れた。 セルラーゼ I の反応至適 $\mathrm{pH}$ および温度は, それぞ

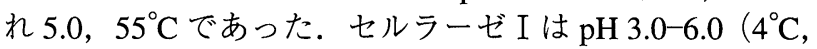
24 時間処理), $55^{\circ} \mathrm{C}$ 以下において，それぞれ $100 \%$ の残存 活性を示した。当該酵素は, $5 \mathrm{mM} の \mathrm{Mn}^{2+}, \mathrm{Fe}^{3+}, \mathrm{Hg}^{2+}$ お よび $\mathrm{KMnO}_{4}$ の存在により部分活性阻害を受けた。セル ラーゼIを各種のセルロース性基質に作用させると，い ずれの基質からも最終生成糖として多量のセロビオース および少量のグルコースが得られた。CMCおよび各種セ ロオリゴ糖に対する作用パターンから, 当該酵素の作用 様式は低エンド型であることが判明した。 